Endocrinol. Japon. 1987, 34 (1), 21-28

\title{
Inhibitory Effect of Progesterone on the Postcastration Gonadotrophin Rise in Women
}

\author{
Hisanori MINAKAMI, NaOhide ABE, Kozo KIMURA, \\ HIROSHI NAKAYAMA AND TARO TAMADA \\ Department of Obstetrics and Gynecology, Jichi Medical School, \\ Minamikawachi-machi, Tochigi-ken, 329-04 Japan
}

\begin{abstract}
s
This study was designed to investigate the effects of progesterone on the gonadotrophin rise after bilateral salpingo-oophorectomy (BSO). Twenty-eight regularly menstruating women underwent hysterectomy and BSO during the follicular phase of the menstrual cycle. They were divided into 5 groups depending on the treatment after BSO. Plasma LH and FSH were studied serially for 14 days after BSO and the patterns of LH and FSH rises were contrasted to those observed in the control group which received neither progesterone nor estrogen. LH and FSH levels in the group which were given low dose progesterone only, rose consistently after BSO and these patterns were similar to those seen in the control group. However, the addition of estrogen reduced gonadotrophin rises significantly more than estrogen did alone. Further, the luteal phase level of progesterone solely has a suppressive effect on the gonadotrophin rises after BSO. Our observations suggest that synergism of progesterone with estrogen may exist in suppressing gonadotrophin secretion in the normal luteal phase and should help in understanding why gonadotrophin levels in the luteal phase are lower than those in the follicular phase of the menstrual cycle.
\end{abstract}

It is widely accepted that under normal physiological conditions gonadotrophin secretion is subjected to the negative feedback actions of circulating sex steroid hormones. Gonadotrophin rise after ovariectomy is thought to be due in part to the decrease in circulating sex steroid hormones. Although the inhibitory effect of estrogen on the gonadotrophin rise after ovariectomy is well known it still remains undetermined whether or not progesterone plays a significant role in suppressing gonadotrophin rise after ovari-

Received May 23, 1986 ectomy in women. In animals and women it has been observed that the maintenance of circulating estradiol alone at concentrations characteristic of the normal follicular phase was insufficient to prevent the rise in circulating gonadotrophins following ovariectomy (Karsch et al., 1973, Simon \& diZerega 1982). We previously reported that a luteal phase level of progesterone alone decreases the frequency of LH pulses, augments their amplitude, and lowers the basal levels of LH and FSH in hypogonadal women (Minakami et al., 1984) Our observations are in good agreement with the report by Karsch 
et al. (1980) that in sheep, simulation of the luteal phase pattern of progesterone alone could reduce $\mathrm{LH}$ concentrations which were intermediate between the elevated levels in ovariectomized non-treated controls and the basal levels in intact controls. These findings suggest that progesterone alone has an inhibitory effect on the gonadotrophin rise after castration in women. Since few data are available concerning this issue, we designed the present study.

\section{Materials and Methods}

Twenty-eight regularly menstruating patients aged 36-51 yr with uterine fibroids were studied. These women had not received any hormonal medication for at least 3 months. The full na- ture of the study was explained to them. They consented to take part in this study and to have bilateral salpingo-oophorectomy (BSO) performed at the time of hysterectomy. Hysterectomy and BSO was performed in all patients in the early to mid-follicular phase of the menstrual cycle. Five patients were treated with intra-muscular(im) injections of $250 \mathrm{mg}$ hydroxyprogesterone caproate (HPC) at $0800 \mathrm{~h}$ on the day of surgery and on day 7 after BSO (Group HPC). The second group of 5 patients were given im injections of $10 \mathrm{mg}$ progesterone at 0800 and $2000 \mathrm{~h}$, (twice daily) beginning on the day of surgery, for 15 consecutive days (Group P). The third group of 5 patients were treated with im injections of $2.0 \mathrm{mg}$ of estradiol benzoate $\left(\mathrm{E}_{2} \mathrm{~B}\right)$ at $0800 \mathrm{~h}$ on the day of surgery and on days 3, 6, 9 and 12 after BSO (Group $E_{2} B$ ). The fourth group of 5 patients received the combined treatment as Group HPC and Group $\mathrm{E}_{2} \mathrm{~B}$ (Group HPC $+\mathrm{E}_{2} \mathrm{~B}$ ). The remaining 8 patients, who received neither

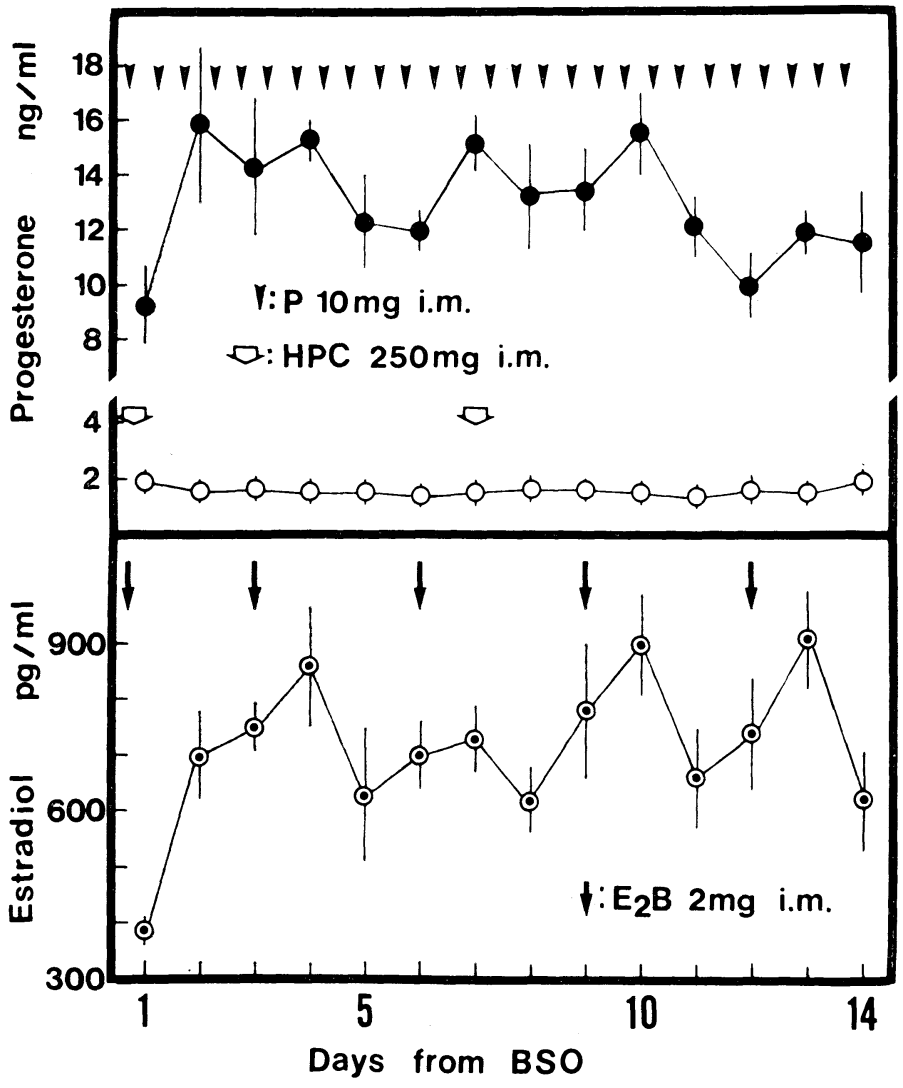

Fig. 1. Daily plasma progesterone concentrations achieved in Group $\mathbf{P}(\mathbf{O})$ and Group HPC (O) (upper panel). Daily plasma estradiol concentrations achieved in Group $\mathrm{E}_{2} \mathrm{~B}$ (๑) (lower panel). Group $P$ $(n=5)$ was given im injections twice daily of $10 \mathrm{mg}$ progesterone beginning on the day of bilateral salpingo-oophorectomy (day 0). Group HPC $(n=5)$ was given im injections of $250 \mathrm{mg}$ hydroxyprogesterone caproate (HPC) on day 0 and 7. Group $E_{2} B$ was given im injections of $2.0 \mathrm{mg}$ of estradiol benzoate $\left(E_{2} B\right)$ on day $0,3,6$, 9 and 12. All values are expressed as the mean \pm SEM. 
progesterone, HPC nor $\mathrm{E}_{2} \mathrm{~B}$ acted as controls. The mean ages ( \pm SD) for Group P, Group HPC, Group $\mathrm{E}_{2} \mathrm{~B}$, Group $\mathrm{HPC}+\mathrm{E}_{2} \mathrm{~B}$ and the control group were $45.4 \pm 2.0,44.0 \pm 3.2,45.6 \pm 3.0,46.6 \pm$ 2.5 and $45.1 \pm 4.5$, respectively. They did not differ significantly. For 16 consecutive days, beginning 2 days before the operation, blood samples were collected once a day between 0900 $1100 \mathrm{~h}$ in all patients. All plasma samples were separated immediately and stored at $-20^{\circ} \mathrm{C}$ until analyzed for $\mathrm{LH}, \mathrm{FSH}$, progesterone and estradiol by radioimmunoassay, as previously described (Minakami et al., 1984). Intra- and interassay coefficients of variation for both $\mathrm{LH}$ and FSH did not exceed $7 \%$ and $11 \%$, respectively. To minimize the effects of interassay variation all samples obtained from a single patient were assayed in a single radioimmunoassay for $\mathrm{LH}$ and FSH. Data were analyzed using analysis of variance, with subsequent Student's $t$-testing when applicable.

\section{Results}

The circulating levels of progesterone and estradiol achieved in Groups P, HPC and $E_{2} B$ are shown in Fig. 1. The twice daily im injections of $10 \mathrm{mg}$ progesterone resulted in maintaining high levels of circulating progesterone $(9.3 \pm 1.4-15.8 \pm 2.8 \mathrm{ng} /$ $\mathrm{m} 1)$. In contrast, the concentration of progesterone in the group given $250 \mathrm{mg}$ HPC intramuscularly on days 0 and 7 remained at low levels $(1.3 \pm 0.4-1.9 \pm 0.4 \mathrm{ng} / \mathrm{ml})$ (Fig. 1 upper panel). $2.0 \mathrm{mg}$ of $\mathrm{E}_{2} \mathrm{~B}$ im injections on days $0,3,9$ and 12 resulted in considerable daily fluctuation in the circulating estradiol level. However, it remained relatively high (Fig. 1. lower panel).

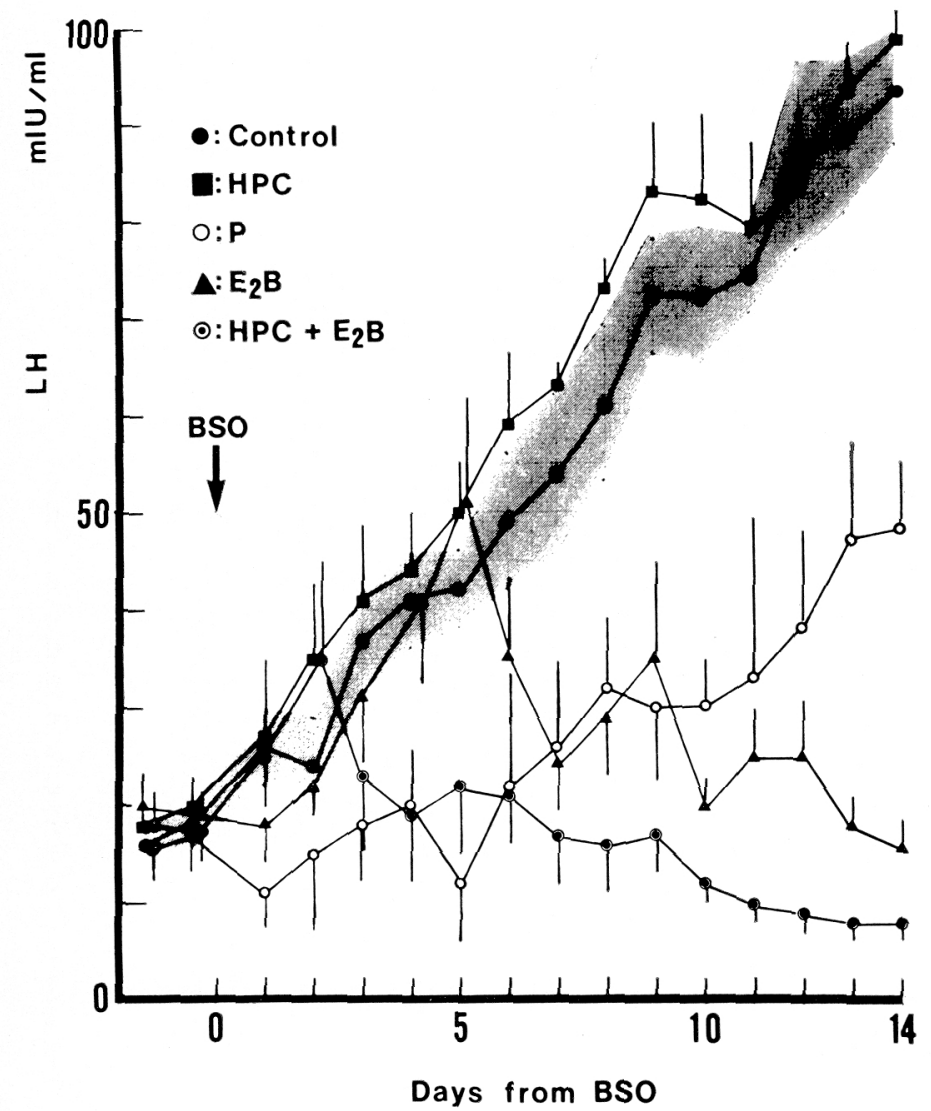

Fig. 2. Daily plasma LH concentrations before and after bilateral salpingo-oophorectomy (BSO, day 0) in groups HPC (ם), P (○), $\mathrm{E}_{2} \mathrm{~B}(\boldsymbol{\Delta}), \mathrm{HPC}+$ $\mathrm{E}_{2} \mathbf{B}(\odot)$ and control $(\bullet)$. The control group $(n=8)$ received neither $\mathrm{E}_{2} \mathrm{~B}$ nor progestin after BSO. Group $\mathrm{HPC}+\mathrm{E}_{2} \mathrm{~B}(\mathrm{n}=$ 5) was given the combined treatment as Group HPC and Group $E_{2} B$. The shaded area shows the \pm SEM of plasma LH in the control group. Other explanations same as for Fig. 1. 


\section{Plasma LH changes}

Fig. 2 demonstrates the plasma concentration of $\mathrm{LH}$ before and after $\mathrm{BSO}$ in Groups $\mathrm{HPC}, \quad \mathrm{P}, \mathrm{E}_{2} \mathrm{~B}, \mathrm{HPC}+\mathrm{E}_{2} \mathrm{~B}$ and control. In the control group and Group HPC, LH levels rose consistently after BSO and significantly increased over preoperative levels on day 3 postoperatively (Table 1). LH levels in Group $\mathrm{P}$ also rose consistently after BSO, but the course of plasma $\mathrm{LH}$ rise was modest and a significant increase in LH was not found until day 13 postoperation (Table 1). Further, LH levels in Group P were significantly lower than those in Group HPC and the control group from day 4 on postoperation (Table 2). In Group $\mathrm{E}_{2} \mathrm{~B}$, a significant increase in $\mathrm{LH}$ above the preoperation value occurred only on days 4 and 5 (Table 1). When compared with the control group, significant low levels of

Table 1. Statistically significant differences when compared to preoperation values. *: N.S., a : p $<0.05, b: p<0.02, c: p<0.01, d: p<0.001$

\begin{tabular}{|c|c|c|c|c|c|c|c|c|c|c|c|c|c|c|c|}
\hline \multirow{2}{*}{ Treatment } & & \multicolumn{14}{|c|}{ Days from BSO } \\
\hline & & 1 & 2 & 3 & 4 & 5 & 6 & 7 & 8 & 9 & 10 & 11 & 12 & 13 & 14 \\
\hline \multirow{2}{*}{ Control } & LH & * & $*$ & b & c & c & c & c & d & d & d & d & $\mathrm{d}$ & d & $\mathrm{d}$ \\
\hline & FSH & $*$ & $*$ & b & c & c & $\mathrm{d}$ & d & d & d & d & d & d & d & d \\
\hline \multirow[b]{2}{*}{ HPC } & LH & $*$ & * & $b$ & $\mathrm{c}$ & d & $\mathrm{d}$ & d & d & d & d & d & d & d & d \\
\hline & FSH & $*$ & * & $\mathrm{c}$ & $\mathrm{c}$ & d & $\mathrm{d}$ & d & d & d & d & d & d & d & d \\
\hline \multirow{2}{*}{$\mathbf{P}$} & LH & $*$ & $*$ & $*$ & $*$ & $*$ & $*$ & $*$ & $*$ & $*$ & $*$ & * & $*$ & $\mathrm{c}$ & $\mathrm{c}$ \\
\hline & FSH & $*$ & * & * & $*$ & $*$ & $*$ & * & $*$ & $*$ & $*$ & $*$ & $*$ & $\mathrm{a}$ & $\begin{array}{l}\mathrm{a} \\
*\end{array}$ \\
\hline $\mathrm{E}_{2} \mathrm{~B}$ & $\begin{array}{l}\text { LH } \\
\text { FSH }\end{array}$ & $*$ & * & $*$ & $\begin{array}{l}\mathrm{a} \\
*\end{array}$ & $\begin{array}{l}\mathrm{b} \\
*\end{array}$ & $\begin{array}{l}* \\
*\end{array}$ & $\begin{array}{l}* \\
*\end{array}$ & $\begin{array}{l}* \\
*\end{array}$ & $\begin{array}{l}* \\
*\end{array}$ & $\begin{array}{l}* \\
*\end{array}$ & $\begin{array}{l}* \\
*\end{array}$ & $\begin{array}{l}* \\
*\end{array}$ & $\begin{array}{l}* \\
\mathrm{a}\end{array}$ & $\begin{array}{l}* \\
\mathrm{a}\end{array}$ \\
\hline \multirow{2}{*}{$\mathrm{HPC}+\mathrm{E}_{2} \mathrm{~B}$} & LH & * & * & * & * & * & $*$ & * & $*$ & $*$ & * & * & $\mathrm{a}$ & $\mathrm{b}$ & $\mathrm{a}$ \\
\hline & FSH & * & * & * & * & $*$ & $*$ & $*$ & * & $\mathrm{a}$ & $\mathrm{a}$ & c & b & $\mathrm{c}$ & c \\
\hline
\end{tabular}

Table 2. Statistically significant differences seen when the two groups were compared. Other explanations are the same as for Table 1.

\begin{tabular}{|c|c|c|c|c|c|c|c|c|c|c|c|c|c|c|c|c|}
\hline \multirow{2}{*}{\multicolumn{3}{|c|}{ Comparison of the two groups }} & \multicolumn{14}{|c|}{ Days from BSO } \\
\hline & & & 1 & 2 & 3 & 4 & 5 & 6 & 7 & 8 & 9 & 10 & 11 & 12 & 13 & 14 \\
\hline Control & v.s. HPC & $\begin{array}{l}\text { LH } \\
\text { FSH }\end{array}$ & $\begin{array}{l}* \\
*\end{array}$ & $\begin{array}{l}* \\
*\end{array}$ & $\begin{array}{l}* \\
*\end{array}$ & $\begin{array}{l}* \\
*\end{array}$ & $\begin{array}{l}* \\
*\end{array}$ & $\begin{array}{l}* \\
*\end{array}$ & $\begin{array}{l}* \\
*\end{array}$ & $\begin{array}{l}* \\
*\end{array}$ & $\begin{array}{l}* \\
*\end{array}$ & $\begin{array}{l}* \\
*\end{array}$ & $\begin{array}{l}* \\
*\end{array}$ & $\begin{array}{l}* \\
*\end{array}$ & $\begin{array}{l}* \\
*\end{array}$ & * \\
\hline Control & v.s. P & $\begin{array}{l}\text { LH } \\
\text { FSH }\end{array}$ & $\begin{array}{l}\mathrm{a} \\
\mathrm{a}\end{array}$ & $\begin{array}{l}* \\
\mathrm{a}\end{array}$ & $\begin{array}{l}* \\
\text { c }\end{array}$ & $\begin{array}{l}\mathrm{a} \\
\mathrm{b}\end{array}$ & $\begin{array}{l}\mathrm{c} \\
\mathrm{c}\end{array}$ & $\begin{array}{l}* \\
\mathrm{~b}\end{array}$ & $\begin{array}{l}\mathrm{a} \\
\mathrm{b}\end{array}$ & $\begin{array}{l}\mathrm{a} \\
\mathrm{b}\end{array}$ & $\begin{array}{l}\mathrm{c} \\
\mathrm{b}\end{array}$ & $\begin{array}{l}\mathrm{c} \\
\mathrm{b}\end{array}$ & $\begin{array}{l}\mathrm{b} \\
\mathrm{c}\end{array}$ & $\begin{array}{l}\mathrm{b} \\
\mathrm{c}\end{array}$ & $\begin{array}{l}\mathrm{b} \\
\mathrm{a}\end{array}$ & $\begin{array}{l}\mathrm{d} \\
\mathrm{a}\end{array}$ \\
\hline Control & v.s. $E_{2} B$ & $\begin{array}{l}\text { LH } \\
\text { FSH }\end{array}$ & $\begin{array}{l}* \\
*\end{array}$ & $\begin{array}{l}* \\
*\end{array}$ & * & $\begin{array}{l}* \\
\mathrm{c}\end{array}$ & $\begin{array}{l}* \\
\mathrm{~b}\end{array}$ & $\begin{array}{l}* \\
\mathrm{c}\end{array}$ & $\begin{array}{l}\mathrm{a} \\
\mathrm{d}\end{array}$ & $\begin{array}{l}\mathrm{a} \\
\mathrm{d}\end{array}$ & $\begin{array}{l}\mathrm{c} \\
\mathrm{d}\end{array}$ & $\begin{array}{l}\mathrm{d} \\
\mathrm{d}\end{array}$ & $\begin{array}{l}\mathrm{d} \\
\mathrm{d}\end{array}$ & $\begin{array}{l}\mathrm{d} \\
\mathrm{d}\end{array}$ & $\begin{array}{l}\mathrm{d} \\
\mathrm{d}\end{array}$ & $\begin{array}{l}\mathrm{d} \\
\mathrm{d}\end{array}$ \\
\hline Control & v.s. $\mathrm{HPC}+\mathrm{E}_{2} \mathrm{~B}$ & $\begin{array}{l}\text { LH } \\
\text { FSH }\end{array}$ & $\begin{array}{l}* \\
*\end{array}$ & $\begin{array}{l}* \\
*\end{array}$ & * & $\begin{array}{l}\mathrm{a} \\
\mathrm{c}\end{array}$ & $\begin{array}{l}\mathrm{a} \\
\mathrm{c}\end{array}$ & $\begin{array}{l}\mathrm{b} \\
\mathrm{d}\end{array}$ & $\begin{array}{l}\mathrm{c} \\
\mathrm{d}\end{array}$ & $\begin{array}{l}\mathrm{c} \\
\mathrm{d}\end{array}$ & $\begin{array}{l}\mathrm{d} \\
\mathrm{d}\end{array}$ & $\begin{array}{l}\mathrm{d} \\
\mathrm{d}\end{array}$ & $\begin{array}{l}\mathrm{d} \\
\mathrm{d}\end{array}$ & $\begin{array}{l}\mathrm{d} \\
\mathrm{d}\end{array}$ & $\begin{array}{l}\mathrm{d} \\
\mathrm{d}\end{array}$ & $\begin{array}{l}\mathrm{d} \\
\mathrm{d}\end{array}$ \\
\hline HPC & v.s. $\mathbf{P}$ & $\begin{array}{l}\text { LH } \\
\text { FSH }\end{array}$ & $\begin{array}{l}* \\
*\end{array}$ & $\begin{array}{l}* \\
\mathrm{~b}\end{array}$ & $\begin{array}{l}* \\
\mathrm{~b}\end{array}$ & $\begin{array}{l}\mathrm{a} \\
\mathrm{c}\end{array}$ & $\begin{array}{l}\mathrm{d} \\
\mathrm{d}\end{array}$ & $\begin{array}{l}\mathrm{a} \\
\mathrm{b}\end{array}$ & $\begin{array}{l}\mathrm{c} \\
\mathrm{c}\end{array}$ & $\begin{array}{l}\mathrm{c} \\
\mathrm{c}\end{array}$ & $\begin{array}{l}\mathrm{d} \\
\mathrm{c}\end{array}$ & $\begin{array}{l}\mathrm{c} \\
\mathrm{c}\end{array}$ & $\begin{array}{l}* \\
\mathrm{c}\end{array}$ & $\begin{array}{l}\mathrm{c} \\
\mathrm{a}\end{array}$ & $\begin{array}{l}\mathrm{c} \\
\mathrm{a}\end{array}$ & $\begin{array}{l}\mathrm{c} \\
\mathrm{a}\end{array}$ \\
\hline HPC & v.s. $\mathrm{E}_{2} \mathrm{~B}$ & $\begin{array}{l}\text { LH } \\
\text { FSH }\end{array}$ & $\begin{array}{l}* \\
*\end{array}$ & $\begin{array}{l}* \\
*\end{array}$ & $\begin{array}{l}* \\
\mathrm{~b}\end{array}$ & $\begin{array}{l}* \\
\mathrm{c}\end{array}$ & $\begin{array}{l}* \\
\mathrm{~d}\end{array}$ & $\begin{array}{l}* \\
\mathrm{~d}\end{array}$ & $\begin{array}{l}\mathrm{d} \\
\mathrm{d}\end{array}$ & $\begin{array}{l}\mathrm{d} \\
\mathrm{d}\end{array}$ & $\begin{array}{l}\mathrm{c} \\
\mathrm{d}\end{array}$ & $\begin{array}{l}\mathrm{d} \\
\mathrm{d}\end{array}$ & $\begin{array}{l}\mathrm{d} \\
\mathrm{d}\end{array}$ & $\begin{array}{l}d \\
d\end{array}$ & $\begin{array}{l}\mathrm{d} \\
\mathrm{d}\end{array}$ & $\begin{array}{l}\mathrm{d} \\
\mathrm{d}\end{array}$ \\
\hline HPC & v.s. $\mathrm{HPC}+\mathrm{E}_{2} \mathrm{~B}$ & $\begin{array}{l}\text { LH } \\
\text { FSH }\end{array}$ & $\begin{array}{l}* \\
*\end{array}$ & $\begin{array}{l}* \\
*\end{array}$ & $\begin{array}{l}* \\
\mathrm{~b}\end{array}$ & $\begin{array}{l}\mathrm{a} \\
\mathrm{c}\end{array}$ & $\begin{array}{l}\mathrm{b} \\
\mathrm{d}\end{array}$ & $\begin{array}{l}\mathrm{c} \\
\mathrm{d}\end{array}$ & $\begin{array}{l}\mathrm{d} \\
\mathrm{d}\end{array}$ & $\begin{array}{l}\mathrm{d} \\
\mathrm{d}\end{array}$ & $\begin{array}{l}\mathrm{d} \\
\mathrm{d}\end{array}$ & $\begin{array}{l}\mathrm{d} \\
\mathrm{d}\end{array}$ & $\begin{array}{l}\mathrm{d} \\
\mathrm{d}\end{array}$ & $\begin{array}{l}\mathrm{d} \\
\mathrm{d}\end{array}$ & $\begin{array}{l}\mathrm{d} \\
\mathrm{d}\end{array}$ & $\begin{array}{l}\mathrm{d} \\
\mathrm{d}\end{array}$ \\
\hline $\mathbf{P}$ & v.s. $\mathrm{E}_{2} \mathrm{~B}$ & $\begin{array}{l}\text { LH } \\
\text { FSH }\end{array}$ & $\begin{array}{l}* \\
*\end{array}$ & $\begin{array}{l}* \\
*\end{array}$ & $\begin{array}{l}* \\
*\end{array}$ & * & $\begin{array}{l}\mathrm{b} \\
*\end{array}$ & $\begin{array}{l}* \\
*\end{array}$ & $\begin{array}{l}* \\
*\end{array}$ & $\begin{array}{l}* \\
*\end{array}$ & $\begin{array}{l}* \\
*\end{array}$ & * & $\begin{array}{l}* \\
*\end{array}$ & $\begin{array}{l}* \\
\mathrm{a}\end{array}$ & $\begin{array}{l}\mathrm{a} \\
\mathrm{a}\end{array}$ & $\begin{array}{l}\mathrm{c} \\
\mathrm{a}\end{array}$ \\
\hline $\mathbf{P}$ & v.s. $\mathrm{HPC}+\mathrm{E}_{2} \mathrm{~B}$ & $\begin{array}{l}\text { LH } \\
\text { FSH }\end{array}$ & $\begin{array}{l}* \\
*\end{array}$ & $\begin{array}{l}* \\
*\end{array}$ & $\begin{array}{l}* \\
*\end{array}$ & $\begin{array}{l}* \\
*\end{array}$ & $\begin{array}{l}* \\
*\end{array}$ & $\begin{array}{l}* \\
*\end{array}$ & $\begin{array}{l}* \\
*\end{array}$ & $\begin{array}{l}* \\
*\end{array}$ & $\begin{array}{l}* \\
*\end{array}$ & $\begin{array}{l}* \\
\mathrm{a}\end{array}$ & $\begin{array}{l}\mathrm{a} \\
\mathrm{a}\end{array}$ & $\begin{array}{l}\mathrm{a} \\
\mathrm{a}\end{array}$ & $\begin{array}{l}\mathrm{a} \\
\mathrm{b}\end{array}$ & $\begin{array}{l}* \\
\mathrm{a}\end{array}$ \\
\hline $\mathrm{E}_{2} \mathrm{~B}$ & v.s. $\mathrm{HPC}+\mathrm{E}_{2} \mathrm{~B}$ & $\begin{array}{l}\text { LH } \\
\text { FSH }\end{array}$ & $\begin{array}{l}* \\
*\end{array}$ & $\begin{array}{l}* \\
*\end{array}$ & $\begin{array}{l}* \\
*\end{array}$ & $\begin{array}{l}* \\
*\end{array}$ & $\begin{array}{l}* \\
*\end{array}$ & $\begin{array}{l}* \\
*\end{array}$ & $\begin{array}{l}* \\
*\end{array}$ & $\begin{array}{l}* \\
*\end{array}$ & $\begin{array}{l}* \\
*\end{array}$ & $\begin{array}{l}* \\
*\end{array}$ & * & a & $\begin{array}{l}\mathrm{c} \\
*\end{array}$ & $\begin{array}{l}\mathrm{d} \\
*\end{array}$ \\
\hline
\end{tabular}


LH were observed from day 7 on postoperation (Table 2). In Group $\mathrm{HPC}+\mathrm{E}_{2} \mathrm{~B}$, LH levels did not show a significant increase above the preoperation value and they decreased significantly from day 13 (Table 1). In addition, from day 12 on, an $\mathrm{LH}$ level in Group $\mathrm{HPC}+\mathrm{E}_{2} \mathrm{~B}$ was significantly lower than that in Group $E_{2} B$ Table 2).

\section{Plasma FSH changes}

Changes in plasma FSH in the 5 groups before and after BSO are shown in Fig. 3. The mode of plasma FSH change was similar in both the control group and Group HPC to that in $\mathrm{LH}$ changes. The first significant rise in FSH above the preoperative level was seen by day 3 in both groups (Table 1). Also, FSH levels in Group P rose con- sistently after $\mathrm{BSO}$, but the course of the plasma FSH rise was modest. Consequently, a significant rise in FSH above the preoperative level was not seen until day 13 . In Groups $\mathrm{E}_{2} \mathrm{~B}$ and $\mathrm{HPC}+\mathrm{E}_{2} \mathrm{~B}$, FSH levels after BSO never exceeded the preoperative levels and dropped significantly by day 12 and 9 , respectively (Table 1 ).

\section{Discussion}

Our results show that the low level of plasma progesterone does not affect the postcastration gonadotrophin rise. The low level of plasma progesterone does, however, facilitate the suppressive effect of estrogen, while the luteal phase level of progesterone acts solely to suppress the gonadotrophin

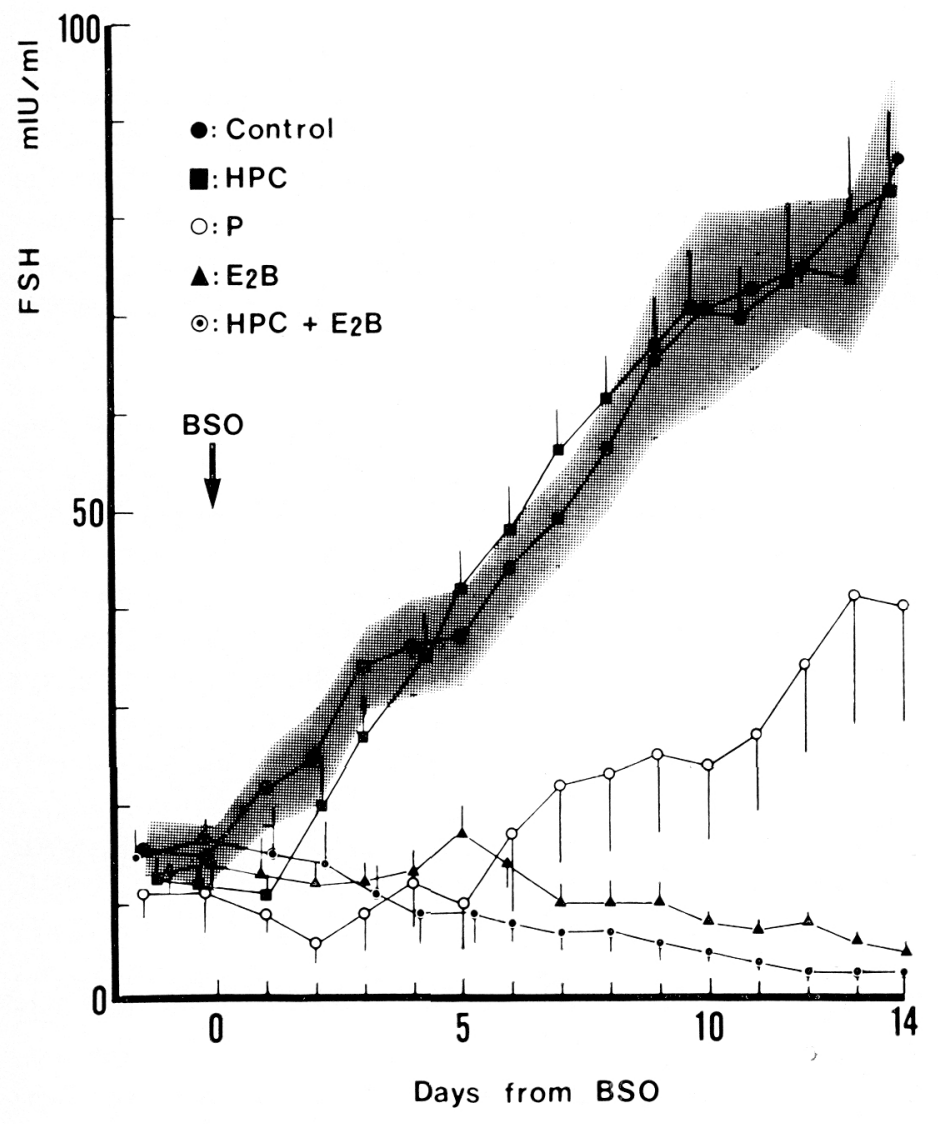

Fig. 3. Daily plasma FSH concentrations before and after bilateral salpingooophorectomy (BSO, day $0)$. Other explanations are the same as for Fig. 2. 
rise after castration in women. In control subjects and Group HPC, a prompt and significant increase in the gonadotrophins was observed during the first 14 days after castration. In contrast, distinctly different patterns in the postcastration gonadotrophin rise were observed in the other 3 groups from that seen in the control group. It has been reported that some differences in the pattern of the postcastration gonadotrophin rise could be observed relative to the ovarian phase of the menstrual cycle, with a more rapid and greater rise in gonadotrophin during the initial phase after castration in preovulatory than postovulatory subjects (Fioretti et al., 1982, Yen \& Tsai 1971). To avoid the influences of ovarian steroids, all patients who participated in this study underwent surgery during the follicular phase of the menstrual cycle. Therefore, the differences in the patterns of godadotrophin rise after castration between groups seen in our study may be attributable to differences in treatment.

An increase in plasma $\mathrm{LH}$ was observed during the first few days after surgery followed by a gradual decline in plasma $\mathrm{LH}$ in Groups $\mathrm{E}_{2} \mathrm{~B}$ and $\mathrm{HPC}+\mathrm{E}_{2} \mathrm{~B}$. This initial rise in LH might be due to the well-known positive feedback effect of estrogen (Araki et al., 1978, Keye \& Jaffe 1975, Nillius \& Wide 1971b, Yen \& Tsai 1972). In the human as well as rhesus monkey, it is well known that at midcycle progesterone starts to rise before $\mathrm{LH}$ and $\mathrm{FSH}$ reach their maximum values (Guerrero et al., 1976, Hoff et al., 1983, Laborde et al., 1976, Weick et al., 1973). This progesterone rise has been thought to advance and augment the following LH peak (Aono et al., 1976, Caligaris et al., 1968, Chang \& Jaffe 1978, Helmond et al., 1981, March et al., 1979). In our study, earlier appearance of an LH peak was seen in the Group $\mathrm{HPC}+\mathrm{E}_{2} \mathrm{~B}$ than in the Group $\mathrm{E}_{2} \mathrm{~B}$. This finding can be explained by an advancing effect of a low progesterone level. Lack of an LH peak in Group $\mathrm{P}$ is probably due to shorter duration of exposure of the hypothalamopituitary system to estrogen than in Groups $\mathrm{E}_{2} \mathrm{~B}$ and $\mathrm{HPC}+\mathrm{E}_{2} \mathrm{~B}$. This interpretation is based on reports that an initiation of a positive feedback effect of sex steroids on gonadotrophin secretion seems to need a certain duration of exposure of the hypothalamo-pituitary system to estrogen (Araki et al., 1978, Keye \& Jaffe 1975). Also, a relatively large dose of progesterone is rather ineffective in inducing an LH peak in estrogen-treated hypogonadal women and monkeys (Helmond et al., 1981, Nillius \& Wide 1971a).

It is recently reported that progesterone administered in the normal follicular phase of the menstrual cycle in women slowed LH pulse frequency, augmented pulse amplitude, and lowered mean plasma LH levels (Soules et al., 1984). Our results show that even low levels of plasma progesterone, which alone were unable to modify gonadotrophin secretion, facilitated the suppressive effect of estrogen. Thus, our findings confirm the report of Soules et al., (1984) and further indicate that subthreshold levels of progesterone in suppressing gonadotrophin secretion can synergize with estrogen in this regard.

The most interesting and novel finding of this report is seen in the effect of progesterone alone on the gonadotrophin rise after castration. To our knowledge, there is no literature concerning this issue. In the present study, we demonstrated that the luteal phase level of progesterone alone can reduce $\mathrm{LH}$ and FSH concentrations which are intermediate between the elevated levels in control subjects and the preoperative value. This result is in agreement with our previous report (Minakami et al., 1984) and others (Bullock et al., 1975, Schiff et al., 1980) that progesterone alone administered to hypogonadal women lowers plasma LH and FSH levels moderately. In contrast, a low level of progesterone did not sup- 
press the gonadotrophin rise after castration.

In summary, the luteal phase level of progesterone alone suppresses the gonadotrophin rise after castration in women. Furthermore, even low levels of progesterone, which alone are unable to suppress gonadotrophin secretion, facilitate the suppressive effect of estrogen. These observations may help in understanding why gonadotrophin levels in the luteal phase are lower than those in the follicular phase of the menstrual cycle (Santen \& Bardin 1973, Sherman \& Korenman 1975).

\section{Acknowledgements}

We wish to thank Miss Yoko Sato and Miss Yasuko Sato for technical assistance, and Miss Mariko Kato for secretarial assistance.

\section{References}

Aono, T., A. Miyake, T. Kinugasa and $\mathrm{K}$. Kurachi (1976). Progesterone advancement of oestrogen-induced luteinizing hormone release during the mid-follicular phase in normal cyclic women. J. Endocr. 71, 451-452.

Araki, S., H. Minakami, S. Konuma, A. Akabori and T. Tamada (1978). Analysis of the positive feedback effect of estrogen on the release of gonadotrophin in women. Endocrinol. Japon. 25, 59-65.

Bullock, J. L., F. M. Massey and R. D. Gambrell, Jr. (1968). Use of medroxyprogesterone acetate to prevent menopausal symptoms. Obstet. Gynecol. 46, 165-168.

Caligaris, L., J. J. Astrada and S. Taleisnik (1968). Stimulating and inhibiting effects of progesterone on the release of luteinizing hormone. Acta Endocrinol. (Copenh) 59, 177-185.

Chang, R. J. and R. B. Jaffe (1978). Progesterone effects on gonadotrophin release in women pretreated with estradiol. J. Clin. Endocrinol. Metab. 47, 119-125.

Fioretti, P., G. Guarnieri, V. Mais, A. M. Paoletti, M. Gambacciani, F. Fruzzetti, V. Facchini, T. Gargiulo, F. Facchinetti and G. B. Melis (1982). Short term effect of gonadectomy on pituitary secretion in females. In: The menopause (P.
Fioretti et al. eds.), Academic press, New York. pp. 81-93.

Guerrero, R., T. Aso, P. F. Brenner, Z. Cekan, B.-M. Landgren, K. Hagenfeldt and E. Diczfalusy (1976). Studies on the pattern of circulating steroids in the normal menstrual cycle. Acta Endocrinol. (Copenh) 81, 133-149.

Helmond, F. A., P. A. Simons and P. R. Hein (1981). Strength and duration characteristics of the facilitory and inhibitory effects of progesterone on the estrogen-induced gonadotrophin surge in the female rhesus monkey. Endocrinology 108, 1837-1842.

Hoff, J. D., M. E. Quigley and S. S. C. Yen (1983). Hormonal dynamics at midcycle: a reevaluation. J. Clin. Endocrinol. Metab. 57, 792-796.

Karsch, F. J., R. F. Weick, J. Hotchkiss, D. J. Dierschke and E. Knobil (1973). An analysis of the negative feedback control of gonadotrophin secretion utilizing chronic implantation of ovarian steroids in ovariectomized rhesus monkey. Endocrinology 93, 478-486.

Karsch, F. J., S. J. Legan, K. D. Ryan and D. L. Foster (1980). Importance of estradiol and progesterone in regulating LH secretion and estrous behavior during the sheep estrous cycle. Biol. Reprod. 23, 404-413.

Keye, W. R. Jr. and R. B. Jaffe (1975). Strengthduration characteristics of estrogen effects on gonadotrophin response to gonadotrophin-releasing hormone in women. I. Effects of varying duration of estradiol administration. $J$. Clin. Endocrinol. Metab. 41, 1003-1008.

Laborde, N., M. Carril, S. Cheviakoff, H. D. Croxatto, E. Pedroza and J. M. Rosner (1976). The secretion of progesterone during the periovulatory period in women with certified ovulation. J. Clin. Endocrinol. Metab. 43, 11571163.

March, C. M., U. Goebelsmann, R. M. Nakamura and D. R. Mishell, Jr. (1979). Roles of estradiol and progesterone in eliciting the midcycle luteinizing hormone and folliclestimulating hormone surges. J. Clin. Endocrinol. Metab. 49, 507-513.

Minakami, H., K. Kimura, H. Yano, T. Kanazawa and T. Tamada (1984). The effects of progesterone on gonadotrophin release in hypogonadal women. Acta Endocrinol. (Copenh) 107, 456-461.

Nillius, S. J. and L. Wide (1971a). Effects of progesterone on the serum levels of FSH and 
LH in postmenopausal women treated with oestrogen. Acta Endocrinol. (Copenh) 67, 362370.

Nillius, S. J. and L. Wide (1971b). Induction of a midcycle-like peak of luteinizing hormone in young women by exogenous oestradiol-17 $\beta$. J. Obstet. Gynaecol. Br. Commonw. 78, 822827.

Santen, R. J. and C. W. Bardin (1973). Episodic luteinizing hormone secretion in man. J. Clin. Invest. 52, 2617-2628.

Schiff, I., D. Tulchinsky, D. Cramer and K. J. Ryan (1980). Oral medroxyprogesterone in the treatment of postmenopausal symptoms. J.A.M.A. 244, 1443-1445.

Sherman, B. M. and S. G. Korenman (1975). Hormonal charateristics of the human menstrual cycle throughout reproductive life. J. Clin. Invest. 55, 699-706.

Simon, J. A. and G. S. diZerega (1982). Physiologic estradiol replacement following oophorectomy: failure to maintain precastration gonadotrophin levels. Obstet. Gynecol. 59, 511-513.

Soules, M. R., R. A. Steinner, D. K. Clifton, N. L. Cohen, S. Aksel and W. J. Bremner (1984). Progesterone modulation of pulsatile luteinizing hormone secretion in normal women. J. Clin. Endocrinol. Metab. 58, 378-383.

Weick, R. F., D. J. Dierschke, F. J. Karsch, W. R. Butler, J. Hotchkiss and E. Knobil (1973). Periovulatory time courses of circulating gonadotrophic and ovarian hormones in the rhesus monkey. Endocrinology 93, 11401147.

Yen, S. S. C. and C. C. Tsai (1971). The effect of ovariectomy on gonadotrophin release. $J$. Clin. Invest. 50, 1149-1153.

Yen, S. S. C. and C. C. Tsai (1972). Acute gonadotrophin release induced by exogenous estradiol during the mid-follicular phase of the menstrual cycle. J. Clin. Endocr. 34, 298305 . 